九八刀著原誌雜會究研事醫堂天順

原苂先的七其現

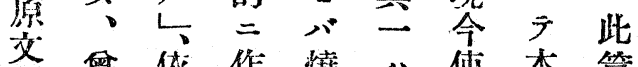

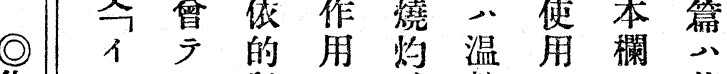

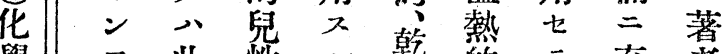

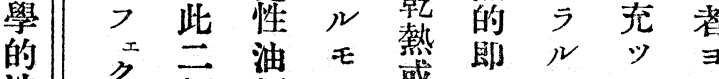

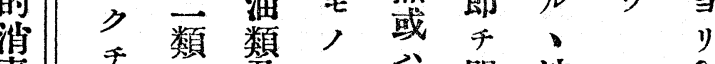

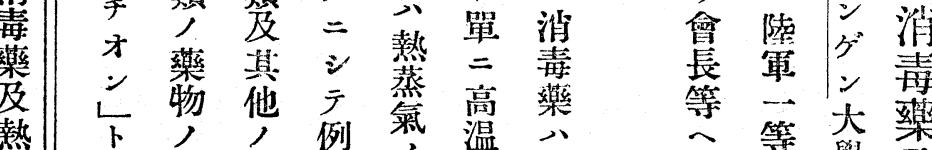

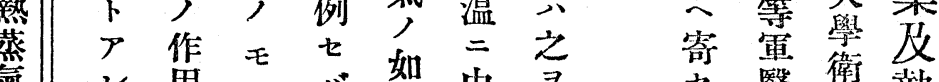

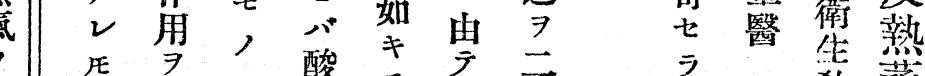

連恐連二酸手作天。无漖蒸

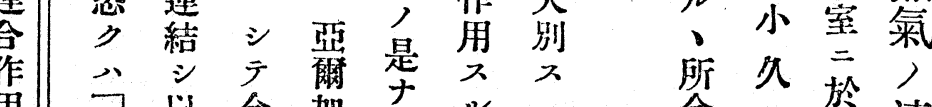

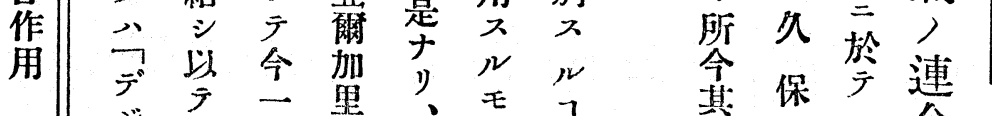

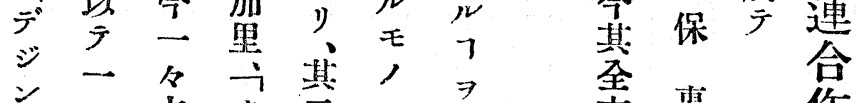

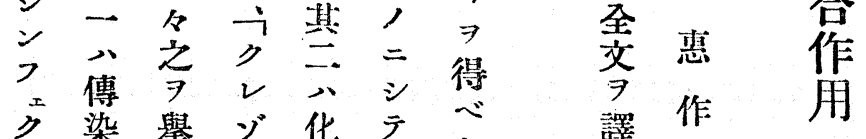

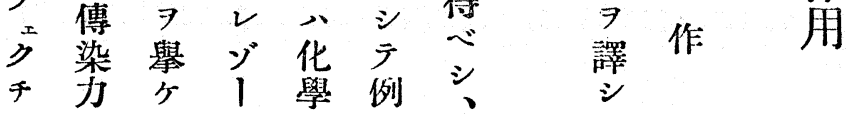

順

天

堂

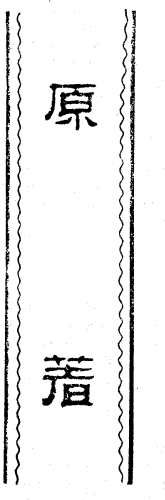

西

車:

研

究

感

鉂

ज范

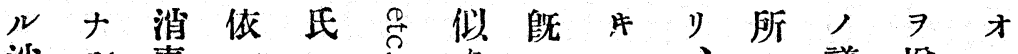

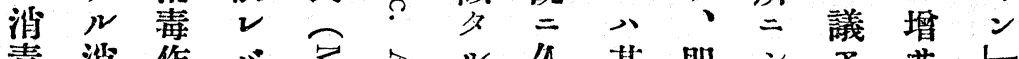

毒溜作

力毒角熱名早事シ通千テリシ 誤

$\exists$ 藥 $\exists$ 酒

得斗有精示宁人室達地: 一

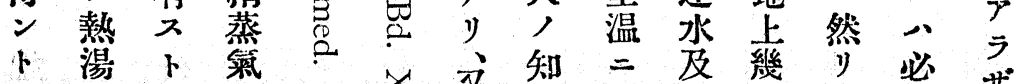

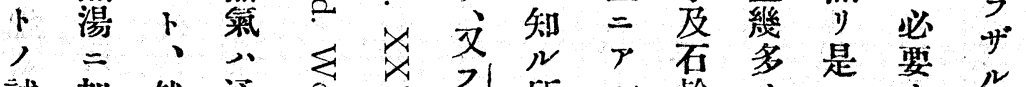

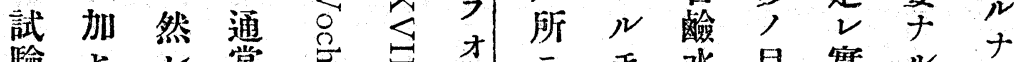

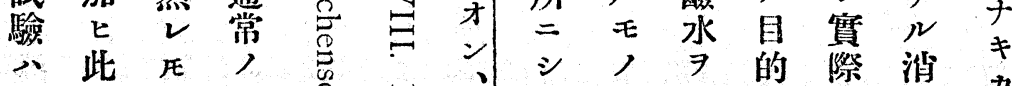

未水余流导

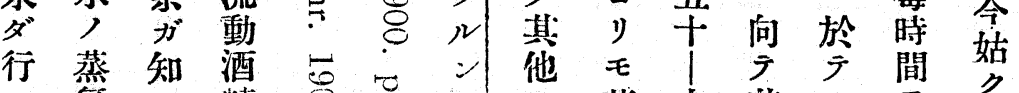

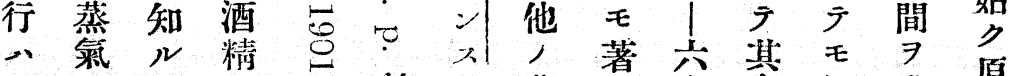

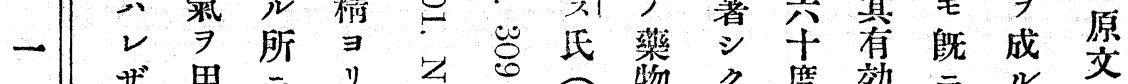

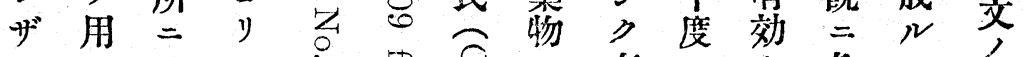

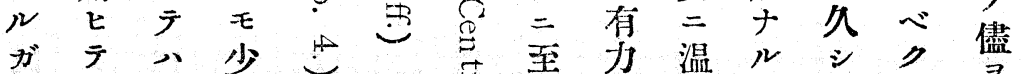

如更化少

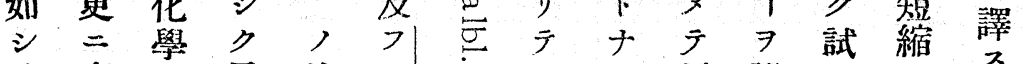

固有考異檢 ラ

第

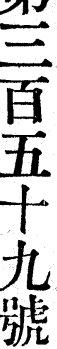

每

月

\#

五.

$\exists ナ$ 勃 


\begin{tabular}{|c|c|c|c|c|c|c|c|c|c|c|c|c|c|c|c|c|}
\hline$=$ & 기 & 此 & 孔 & シ & 試 & 績 & 徥 & 勞 & > & 的 & 易 & M & 沸 & $\bar{\gamma}$ & 七 & $\geqslant$ \\
\hline 用 & オ & 孔 & $\exists$ & 八 & 驗 & $\exists$ & $t$ & 务 & $N$ & 兒 & 3 & 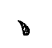 & 騰 & 單 & ザ & 之 \\
\hline t & $=1$ & $=$ & 有 & $=$ & $J$ & 得 & $T^{\circ}$ & 3 & $D$ & 性 & $z$ & 7 & $\ddot{\Sigma}$ & - & $\mu$ & $\bar{\exists}$ \\
\hline シ & 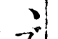 & 被 & $\pi$ & 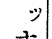 & 順 & 8 & 條 & 儥 & $E$ & 溜 & $\exists$ & 八 & 難 & 水 & 7 & 加 \\
\hline 小 & ᄀ1 & 驗 & $\pi$ & 尔 & 序 & $y$ & $=$ & $\bar{\gamma}$ & ノ & 類 & 證 & 固 & $\neq$ & 蒸 & M & 7 \\
\hline 装 & $\mu$ & 物 & 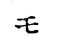 & 比 & $\therefore$ & & 記 & 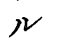 & ナ & ) & $\pi$ & $\exists$ & 化 & 菉 & 經 & N \\
\hline 䈯 & 2 & $\Rightarrow$ & , & 小 & 割 & & x & $\varepsilon$ & y & 如 & べ & リ & 學 & J & 驗 & 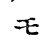 \\
\hline 7 & 代 & 投 & ナ & 蒸 & 合 & & $\pi$ & ノ & 、 & $\neq$ & $\Rightarrow$ & 僅 & 的 & 沸 & 上 & 其 \\
\hline$乇$ & 比 & 入 & y & 登 & $=$ & & 種 & 卜 & 是 & 者 & 即 & $=$ & 物 & 騰 & 知 & 酒 \\
\hline 用 & 力 & $\bar{x}$ & シ & 来 & 簡 & & 8 & 信 & $=$ & $\therefore$ & $F$ & 痕 & 質 & 點 & $N$ & 精 \\
\hline ヒ & 當 & $\therefore$ & ガ & 距 & 單 & & + & シ & 於 & 水 & 香 & 跡 & j & 以. & 所 & $=$ \\
\hline シ & 綮 & z & 多 & & 广 & & $N$ & 7 & $\bar{y}$ & 蒸 & 氮 & $=$ & 單 & 1 & $=$ & 敄 \\
\hline ガ & 室 & $\exists$ & $\Rightarrow$ & シ & リ & & 藥 & 才 & 平 & 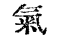 & $\exists$ & 過 & $\therefore$ & $=$ & y & 5 \\
\hline$z$ & $=$ & 除 & $ノ$ & $\vec{\gamma}$ & $\neq$ & & 物 & ע & 余 & 中 & 有 & $\neq$ & 流 & $\gamma$ & 通 & N \\
\hline$=$ & 於 & 去 & 蒸 & 其 & 、 & & $\exists$ & ' & $\therefore$ & $=$ & $\pi$ & ス & 動 & $N$ & $\rightarrow$ & $y$ \\
\hline 就 & $\bar{T}$ & ス & 瓷 & $t$ & 蒸 & & 試 & 7 & 上. & 於 & 2 & $r$ & 水 & 7 & 該 & 奶 \\
\hline テ & 酒 & $N$ & $\exists$ & 方 & 發 & & 驗 & 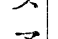 & 記 & $\bar{Y}$ & 葙㘶 & 踓 & 蒸 & $\gamma$ & 漼 & Y \\
\hline$\therefore$ & 精 & 7 & 笑 & $=$ & 鮙 & & " & $\gamma$ & 試 & $E$ & 物 & E & 䳡 & $\nu$ & , & 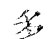 \\
\hline 氏 & 試 & 7 & $\rightarrow$ & 狹 & 1 & & 蒈 & 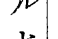 & 悪 & \pm & 例 & 10 & $=$ & 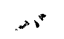 & 沸 & $\frac{3}{18}$ \\
\hline$\pi^{\prime}$ & 驗 & 得 & ズ & $\neq$ & シ & & タ & El & $\exists$ & 㚖 & $z$ & $z$ & il & ナ & 䳽 & $=$ \\
\hline 著 & 7 & $\neq$ & シ & 蒸 & テ & & 程 & 教 & 舉 & 集 & $\therefore$ & $\gamma$ & $\bar{\gamma}$ & y & 點 & 蒸 \\
\hline 論 & 行 & 、 & $\bar{\gamma}$ & 氭 & 余 & & \& & 授 & 行 & $=$ & 數 & 2 & 分 & v & 徃 & 率 \\
\hline$=$ & $\hat{\imath}$ & 及 & 迅 & ノ & $\rightarrow j$ & & ナ & , & $\pi$ & 由 & 多 & -1 & 配 & 祭 & \& & $=$ \\
\hline & $\dot{\Sigma}$ & 算 & 速 & 流 & 用 & & $N$ & 議 & $N$ & $\bar{\gamma}$ & ᄀ & $\rightarrow$ & Ł & $=$ & $=$ & 移 \\
\hline $\mathcal{3}$ & 時 & 广 & $=$ & 出 & $\varepsilon$ & & 成 & $=$ & M & 現 & 依 & 容 & ラ & 此 & $\ddot{z}$ & 行 \\
\hline 間 & 第 & $卜$ & , & べ & 7 & , & $=$ & 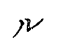 & ラ & 銳 & 器 & り & $\Rightarrow$ & ス & x & $=$ \\
\hline 耊 & $\cdots$ & 欲 & 增 & $\eta$ & 能 & 化 & 由 & 徽 & シ & $\neq$ & $=$ & $\checkmark$ & , & N & 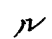 & 於 \\
\hline 沸 & 試 & 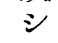 & 加 & 異 & 八 & 學 & $\bar{\gamma}$ & 菌 & 厶 & 香 & 苗 & 7 & 温 & 7 & , & $\bar{J}$ \\
\hline セ & 唂 & タ & ti & ナ & ザ & 的 & 教 & j & 、 & 菊 & $\bar{\gamma}$ & $\pi$ & 度 & $\exists$ & 要 & 訚 \\
\hline シ & 物 & !) & 喿 & $v$ & N & 樂 & 秒 & ミ & 試 & $\gamma$ & 蒸 & 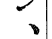 & 及 & 得 & 7 & 7 \\
\hline 後 & 八 & & シ & $n$ & 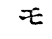 & 物 & 間 & ナ & 驗 & $N$ & 裁 & $フ^{*}$ & 蒸 & べ & 見 & 以。 \\
\hline$=$ & 通 & & テ & $\equiv$ & I & $\exists$ & $=$ & y & 物 & 物 & 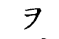 & $\boldsymbol{v}$ & 栽 & ク & $x^{\circ}$ & $\bar{J}$ \\
\hline モ & 常 & & 各 & 種 & r & 加 & 容 & $\neq$ & $p$ & 翼 & 再 & 2 & 7 & 殊 & V & 綿 \\
\hline 其: & , & & 芽 & , & 思 & 七 & 易 & V & シ & $\bar{\xi}$ & $\iota^{*}$ & 21 & 損 & $=$ & 只 & 密 \\
\hline 上 & 馬 & & 萠 & 芽 & E & タ & $\Rightarrow$ & 是 & $\bar{\zeta}$ & 其: & 濃 & 氏 & $t$ & 試 & 二 & $=$ \\
\hline$=$ & 鈴 & & $\exists$ & 萠 & タ & $M$ & 死 & $v$ & 供 & 蒸 & 厚 & $カ^{\prime \prime}$ & $x^{\prime}$ & 驗 & 言 & 記 \\
\hline 生 & 啫 & & 本 & 發 & $v$ & 百 & 減 & 芽 & 七 & 氣 & $=$ & 用 & シ & 物 & z & 述 \\
\hline 存 & 桿 & & 均 & 生 & バ & 度 & $\pi$ & 萠 & シ & $\exists$ & + & 匕 & テ & , & べ & Ł \\
\hline シ & 菌 & & $=$ & 物 & ナ & $ノ$ & $N$ & $ナ$ & > & ע) & ス & シ & 行 & 出 & $\neq$ & シ \\
\hline 笏 & $=$ & & 影 & 7 & リ & 蒸 & 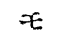 & $\neq$ & 抗 & 室 & , & 斻 & 7 & $\bar{\lambda}$ & $\therefore$ & $\Rightarrow$ \\
\hline 譬 & シ & & 阼 & 擇 & " & 鹤 & ノ & 菌 & 抵 & 內 & 便 & , & T & $=$ & 此 & 以 \\
\hline 膜 & $\bar{J}$ & & ス & $\iota^{*}$ & 余 & 作 & $=$ & M & 力 & $=$ & $\gamma$ & 如 & 7 & $\leadsto$ & 器 & $\bar{\gamma}$ \\
\hline$\exists$ & 此 & & $N$ & 是 & $\rightarrow$ & 用 & シ & 單 & , & 逸 & $n$ & $\eta$ & 得 & 非 & $\longrightarrow$ & 金 \\
\hline 造 & 八 & & $p$ & $=$ & 其: & 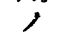 & $\bar{\gamma}$ & $\ldots$ & 强 & 出 & , & 其 & $N$ & 掌 & 甚 & > \\
\hline リ & 馬 & & 否 & 由 & 抗 & 增 & 此 & ر & $\neq$ & . & ミ & 裝 & ノ & $=$ & ダ & 茲 \\
\hline ッ & 鈴 & & $\vec{p}$ & $\bar{\gamma}$ & 抵 & 加 & 譶 & 流 & 芽 & $N$ & + & 䈯 & 便 & 速 & 便 & $=$ \\
\hline • & 薯 & & $\exists$ & 筫 & 力 & 9 & 合 & 動 & 萌 & 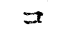 & ラ & セ & ナ & $=$ & 冝 & $z$ \\
\hline 甚 & $\exists$ & & 試 & 消 & ' & 證 & $=$ & 水 & 7 & 卜 & $x^{\prime}$ & $n$ & 2 & 且 & $=$ & $\exists$ \\
\hline タ & 米 & & $\Sigma$ & 靠 & 成 & $x$ & 於 & 秛 & 有 & 勿 & 往 & 冷 & $=$ & \% & 使 & 詳 \\
\hline 鐃 & 時 & & ン & 力 & $N$ & $N$ & $\bar{\gamma}$ & 氮 & ス & 力 & 々 & 却 & $P$ & 多 & 用 & 記 \\
\hline
\end{tabular}


一九入著原誌㗎偣究研事醫堂天順

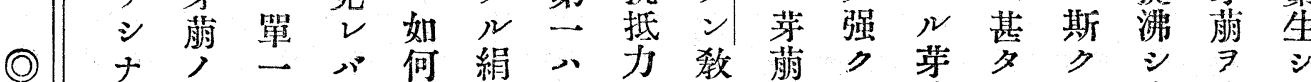

化り抗流明二系通

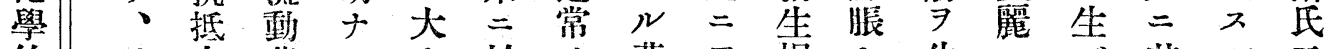

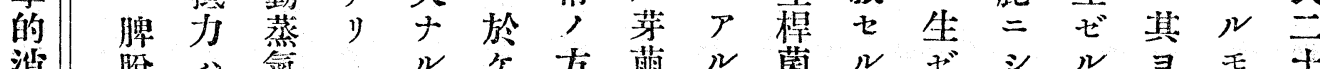

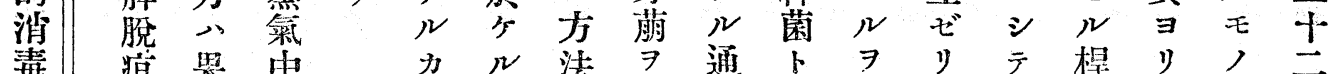

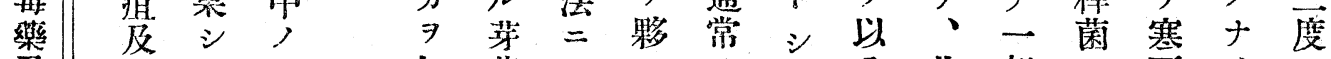

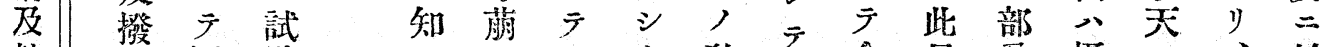

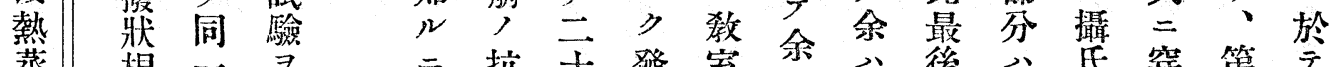

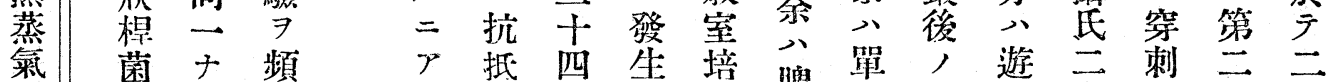

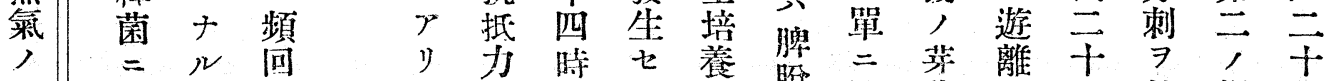

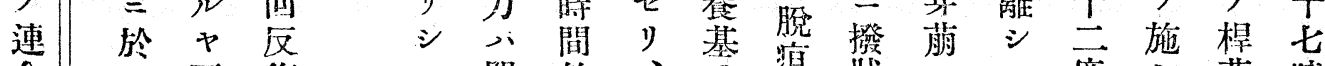

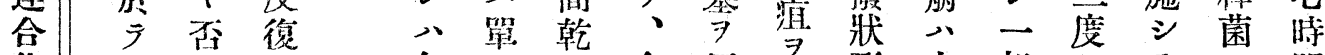

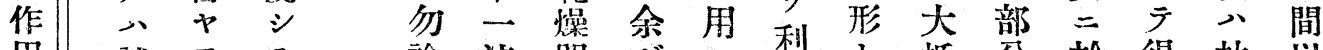

用試 $\exists \overline{5}$ 論流器沓七犁有抵分於得枯以

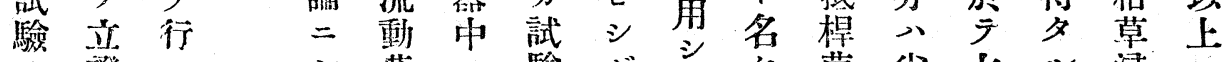

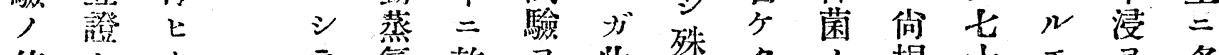

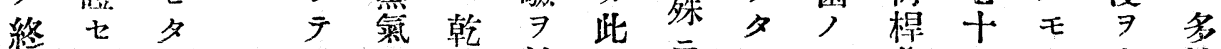

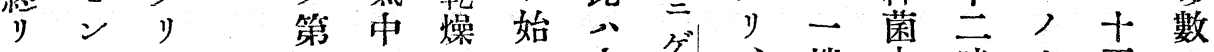

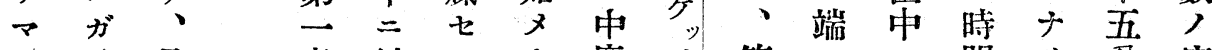

デ篇是表於 シ タ度 千第二二間分完

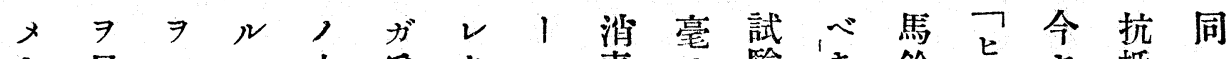

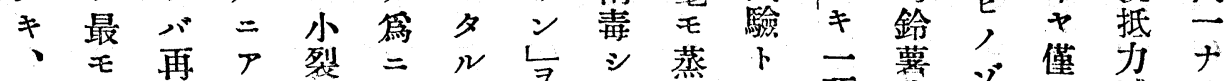

之速

$\exists=$ 器、中絹萠見 $、$ 中

裝裝械此 三 系絹 $コ$ 当

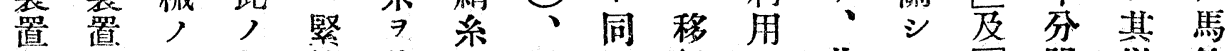

$\exists=$ 挿 如結 装, 最—行

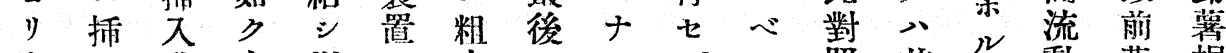

取入孔大以少

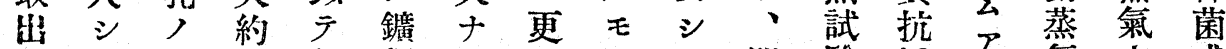

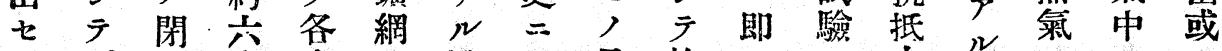

$ル$ 再 鎖 系

後 ビ栓十 7 置厚言古モ外他减デ堪百其

二之三條, カ 水

三 各 除古絹氣 $シ$ 滴

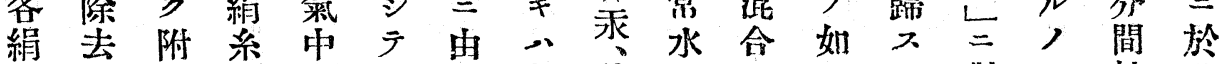

系入着 $\ni=$ 各テ蒸硫

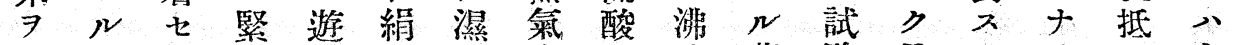

焋 二

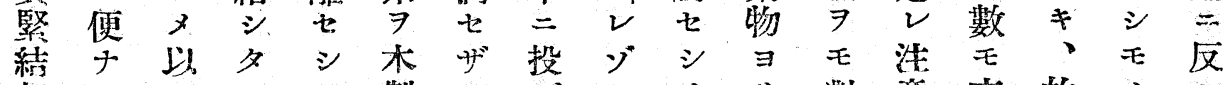

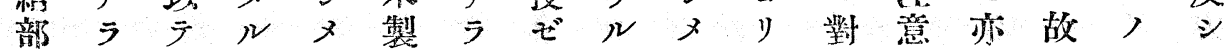

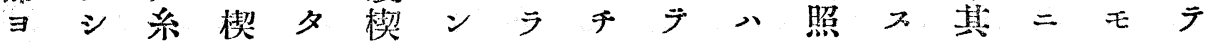




\begin{tabular}{|c|c|c|c|c|c|c|c|c|c|c|c|c|c|c|c|c|}
\hline 此 & $\gamma$ & 多 & 其: & 牌 & 知 & 械 & 次 & 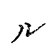 & 雪 & 合 & $\%$ & 㕠 & $\Rightarrow$ & 總 & 卵 & y \\
\hline & ミ & $\equiv$ & 滥 & 脱 & 常 & $\exists$ & デ & ガ & 覱 & 物 & $=$ & 汁 & 條 & $\overline{7}$ & 潭 & 減 \\
\hline 藥 & $>$ & $\%$ & 琵 & 瘨 & 總 & y & 五 & 故。 & $\Rightarrow$ & 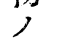 & 穛 & 小 & 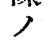 & , & 度 & 葙 \\
\hline$>$ & 更 & F & is & 芽 & 時 & 取 & 㞣 & $=$ & 以 & 作 & 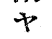 & 管 & 系 & 試 & $=$ & 性 \\
\hline$\rightarrow$ & $=$ & $ナ$ & $\exists$ & 萌 & 間 & 出 & 間 & 余 & $\overline{5}$ & 用 & 詳 & $=$ & $\Rightarrow$ & 驗 & 賀 & 鋏 \\
\hline$\%$ & 0 & シ & 檢 & $=$ & $\exists$ & 七 & $\exists$ & $\rightarrow$ & - & $=$ & 密 & 投 & 取 & $=$ & $\neq$ & $\Rightarrow$ \\
\hline$=$ & 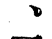 & V & $\pi$ & 於 & 三 & リ & 隔 & 規 & \$ & 就 & + & 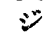 & リ & 於 & $\bar{\gamma}$ & 以。 \\
\hline 於 & $\overrightarrow{0}$ & $\mp$ & 心゙ & $\bar{\gamma}$ & 時 & 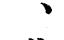 & $\bar{\gamma}$ & 則 & 多 & $\bar{J}$ & $\mathcal{N}$ & $\neq$ & "z & $\bar{\gamma}$ & 每 & テ \\
\hline $\bar{J}$ & $\begin{array}{l}\% o \\
z \\
z\end{array}$ & 只 & $\neq$ & 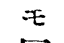 & 問 & 此 & 前 & P & 整 & $\rightarrow$ & 7 & $\checkmark$ & 9 & $\rightarrow$ & B & 切 \\
\hline 既 & n & 7 & 物 & 同 & r & 際 & 德 & シ & 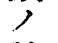 & 淌 & $\exists$ & 斯 & 㔀 & 每 & 筫 & 衒 \\
\hline$=$ & , & オ & 而 & 柡 & ナ & 第 & $=$ & $\bar{T}$ & 試 & 소 & 得 & $\Rightarrow$ & \& & 常 & 發 & シ \\
\hline 非 & 0 & $\nu$ & $\rightarrow$ & $=$ & シ & 鈴 & + & 最 & 驗 & 3 & 2 & $x$ & $=$ & $\Rightarrow$ & 青 & 之 \\
\hline 常 & 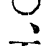 & $\nabla$ & 之 & 持 & 撥 & 澺 & 㔔 & 初 & 7 & $己$ & バ & $v$ & 蒸 & 重 & 加 & $\exists$ \\
\hline ナ & 五 & 1) & $\underset{\exists}{3}$ & 續 & 战 & 柦 & 閐 & ノ & 行 & 7 & ナ & バ & 尧 & $=$ & 何 & 肉 \\
\hline$N$ & $\%$ & 3 & 水 & 七 & 暒 & 荿 & $\exists$ & + & 八 & 和 & $y$ & 怎 & $=$ & Z & $\Rightarrow$ & 器 \\
\hline 消 & ト & $y$ & $=$ & リ & 菌 & $=$ & 隔 & 芬 & ザ & ラ & $\circ$ & 回 & 仵 & $\exists$ & 檢 & 汗 \\
\hline 毒 & シ & $L$ & $\overrightarrow{\text { 和 }^{2}}$ & & $=$ & 於 & $\ddot{\gamma}$ & 閜 & N & ザ & 19 & 棌 & 用 & 行 & 苴 & $=$ \\
\hline 力 & $\bar{\gamma}$ & 及 & 11 & & 於 & 5 & D & $=$ & $\exists$ & y & 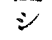 & 葋 & セ & t & 七 & 投 \\
\hline$\gamma$ & 用 & $\overrightarrow{7}$ & ק. & & $\bar{\gamma}$ & N & 必 & 於 & 得 & シ & 余 & 法 & シ & 詳 & $y$ & シ \\
\hline ル & E & V & $=$ & & $>$ & 試 & ス & $\bar{J}$ & ザ & $\exists$ & $\rightarrow$ & r & $x$ & 言 & & 而 \\
\hline 7 & タ & 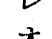 & $=$ & & + & 酚谷 & 試 & $\rightarrow$ & 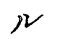 & 以 & 種 & 境 & צ & x & & $y$ \\
\hline 7 & $y$ & $\lambda$ & $\overrightarrow{0}$ & & 然 & $=$ & 驗 & 每 & 八 & $\bar{J}$ & 今 & 界 & $n$ & $v$ & & 频 \\
\hline 證 & V & 1 & 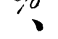 & & 汽 & 於 & 系 & 分 & 勿 & 每 & ナ & $\exists$ & 後 & バ & & 日 \\
\hline シ & 是 & b & $=$ & & ト & $\bar{y}$ & F & 時 & 論 & 回 & ル & 定 & 条 & 每 & & 間 \\
\hline タ & $v$ & $\stackrel{r}{L}$ & $\%$ & & シ & 八 & 器 & $=$ & ナ & 各 & 混 & 公 & 肉 & 6 & & 卿孚 \\
\hline y & 知 & 此 & & & & & ノ & 表 & 殊 & y & 倘 & $=$ & ル & ノ & 會 & $v$ \\
\hline V & N & 表 & 䭾 & & 馬 & & ナ & 八 & $=$ & ' & 生 & ノ & 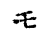 & 數 & シ & バ \\
\hline 何 & べ & F & 䈣 & 第 & 紫 & 第 & リ & $\equiv$ & 出 & 余 & 存 & 殐姿 & ノ & $\exists$ & 易 & ナ \\
\hline 卜 & シ & 比 & 菌 & & 菌 & & & 種 & 來 & ， & シ & $\gamma$ & $=$ & 示 & 力 & リ \\
\hline ナ & 詳 & 䡴 & 百 & $=$ & 石 & - & & 芽 & N & 其: & $=$ & $N$ & シ & x & ラ & $\dot{x}$ \\
\hline$v$ & 言 & x & 音 & & 忢 & & & 萠 & ダ & $\rightarrow$ & 分 & 八 & $\bar{\gamma}$ & $\leadsto$ & シ & $\widehat{\theta}$ \\
\hline க゙ & ス & $n$ & 尣 & 表 & + & 表 & & I & 5 & 覽 & 間 & 第 & 例 & 其: & $x$ & 刑 \\
\hline 若 & $v$ & 用 & 分 & & 分 & & & 單 & 其 & $=$ & 7 & 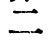 & t & 一 & ン & $\begin{array}{l}x \\
E\end{array}$ \\
\hline シ & バ & 八 & & & & 永 & & $\dot{-i}$ & 化 & 便 & 經 & $\mathcal{J}$ & バ & > & ガ & 0 \\
\hline 然 & 昇 & 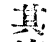 & & & & 烒 & & 流 & 學 & 七 & テ & 試 & $\rightarrow$ & 第 & 䈑 & 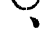 \\
\hline ラ & 永 & 第 & 蕟 & & 撥 & 答 & & 動 & 的 & $\nu$ & 始 & 歌䐍 & $\%$ & 一 & $=$ & $\cdots$ \\
\hline . & 八 & $\cdots$ & 狀 & & 牀 & 坣 & & 蒸 & 分 & ガ & $x$ & $=$ & 醋 & ノ & $\rightarrow$ & $\%$ \\
\hline ト & 蒸 & 及 & 菌 & & 闻 & & & 集 & 数 & 駡 & テ & 於 & 酒夋 & 絹 & $\overrightarrow{\bar{B}}$ & 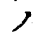 \\
\hline 七 & 氣 & 第 & & & 七 & & & 中 & $=$ & $=$ & 減 & $\bar{\gamma}$ & $=$ & 系 & ス & E \\
\hline バ & 中 & & & & & & & $=$ & 從 & 被 & 菌 & - & 於 & II: & べ & ノ \\
\hline 疑 & $=$ & 表 & 芬 & & 八 & & & 於 & $\bar{\xi}$ & 驗 & Ł & 分 & 5 & 三 & $\neq$ & 9 \\
\hline 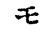 & 移 & $=$ & 䇥 & & 間 & & & $ケ$ & 之 & 藏 & $n$ & 間 & $N$ & 八 & $\rightarrow$ & 用 \\
\hline ナ & 行 & 於 & & & & & & $N$ & $\overline{7}$ & 7 & $\exists$ & 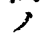 & 牌 & 第 & - & t \\
\hline$\eta$ & 七 & $\bar{\gamma}$ & & & & & & 抗 & 總 & 各 & 意 & 後 & 脫 & 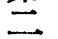 & 部 & タ \\
\hline 其: & ザ & 毫 & 脾 & & 脾 & & & 抵 & 括 & 部 & 味 & $=$ & 㾴。 & ) & 分 & y \\
\hline 强 & $N$ & $\bar{E}$ & 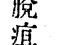 & & $\begin{array}{l}\text { 脫 } \\
\text { 疦 }\end{array}$ & & & 力 & セ & 類 & ス & 絹 & $=$ & 絹 & $=$ & ' \\
\hline 洦 & モ & 萀 & 覴 & & 菌 & & & $\exists$ & y & $=$ & 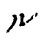 & 系 & 於 & 系 & 於 & 次 \\
\hline 毒 & & ナ & & & & & & 示 & ' & 總 & $\mathcal{E}$ & ノ & $\bar{j}$ & $=$ & $\bar{\gamma}$ & 表 \\
\hline 力 & ' & $\neq$ & 紛 & & 岀 & & & ス & 第 & 括 & , & 一 & 一 & 關 & $=$ & 7 \\
\hline 7 & ナ & 7 & 簡 & & 間 & & & $E$ & - & シ & ナ & $>$ & $!$ & 大 & 種 & 理 \\
\hline
\end{tabular}




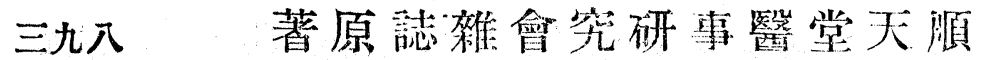

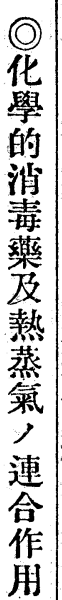

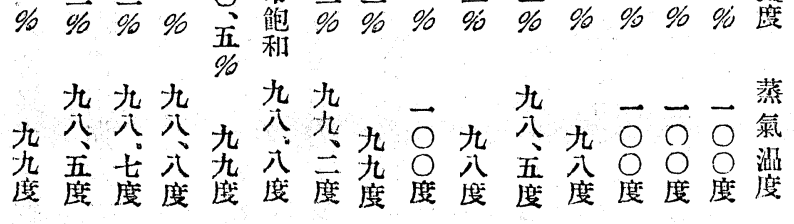

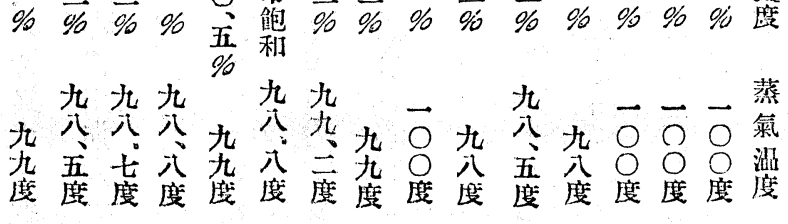

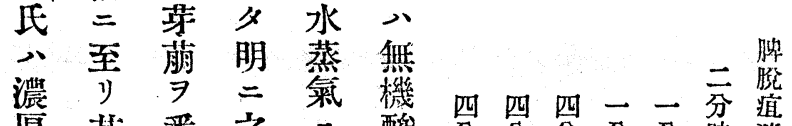

厚其悉之二酸分分分分分分突菌

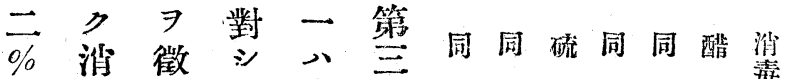

及毒入テ有表酸酸㗼

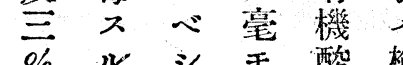

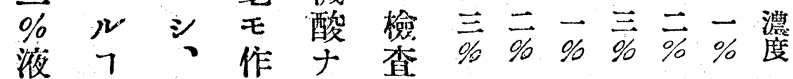

期醋用り七

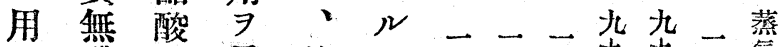

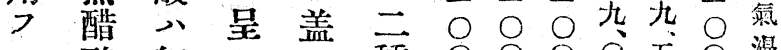

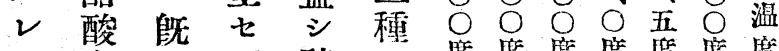

八゙ 水 $=$ ズ硫, 度度应度度度度

作 事 $一$ 酸 酸

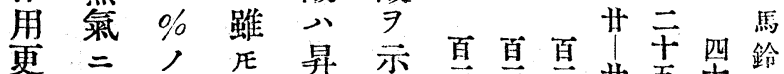

二比稀醋录

强 三 釋酸 1 モ分分分分時時菌

亲 $==$ 等,

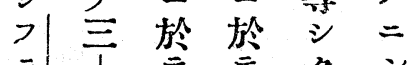

皇

ク倍種甚一一

チこ前血同同y号同同り马同同レ゙同同石消

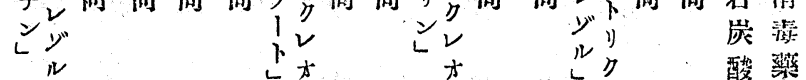

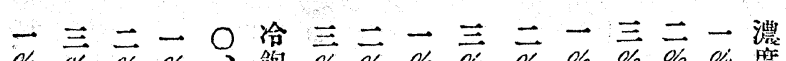

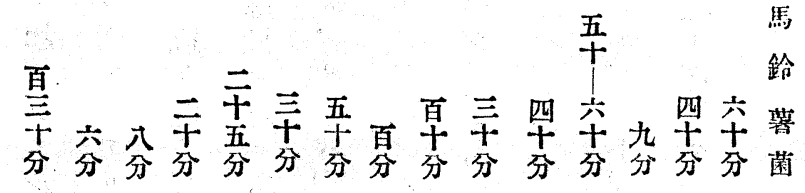

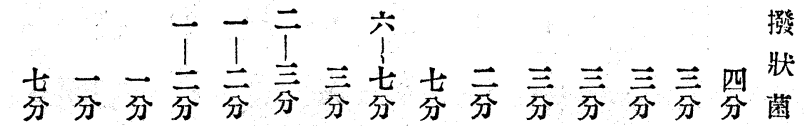

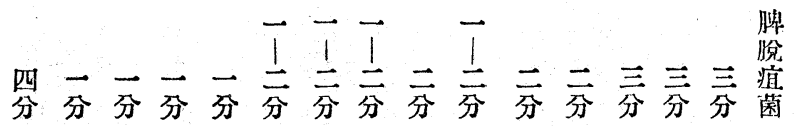

$ル$ 試 卜 雖 現

T驗 其 E 八

第 能 $=$ 其 入

八從發 水 心

バ 入 液

表此 ル尹心゙

フフ沸ナ

如? 膯

* リ ス

非卜儿䒜

常稱牛永

〉七八

稀 亏 少 約

液ル量三

$=v$, 百

於 バ格度

天。魯,

、リ兒 沰

斯、化騰

$几$ 然录 點

$7 v, 7$

ノ辰水有

学余蒸

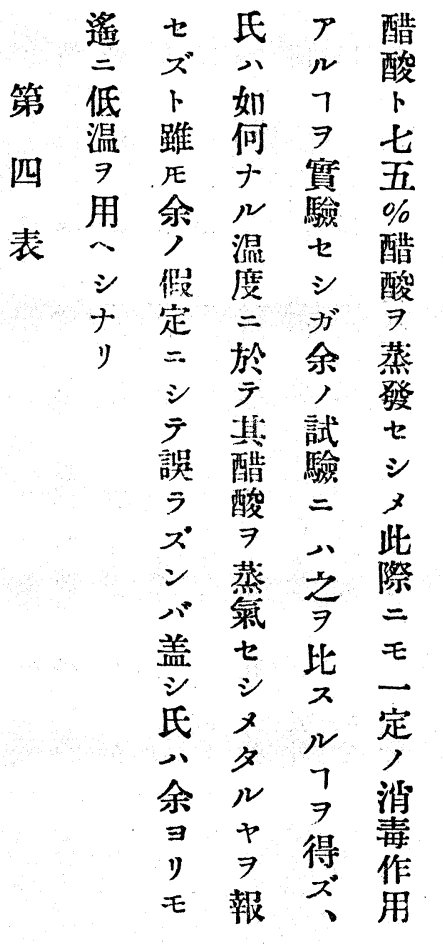




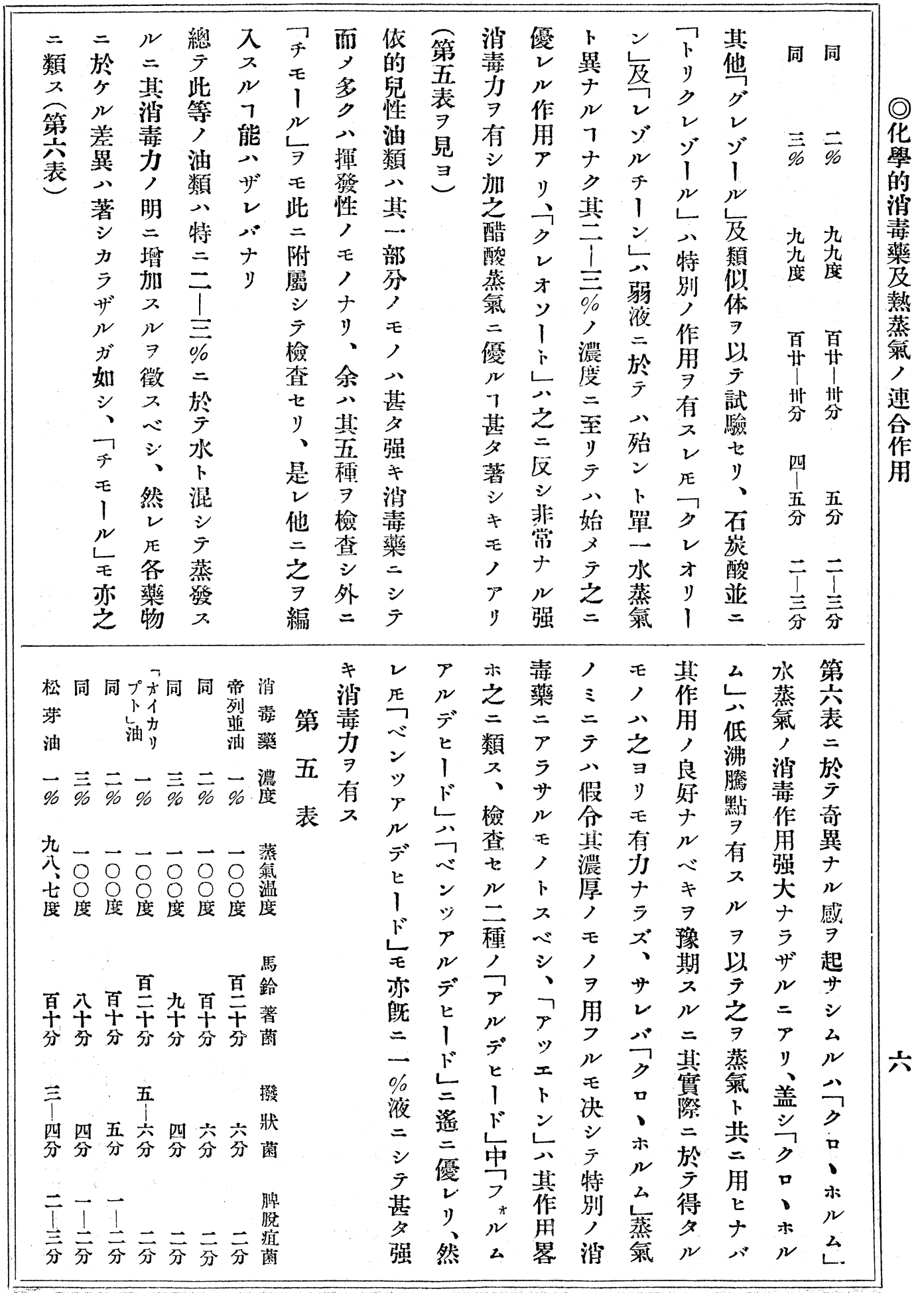


五九分著原誌嚾會究研事醫堂天順

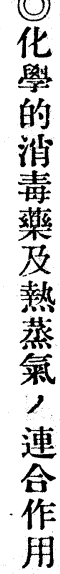

ルヂ同同ルッ泀同油ア同同

同同同同ルラ同同デさ同同ンフ同同ムっ

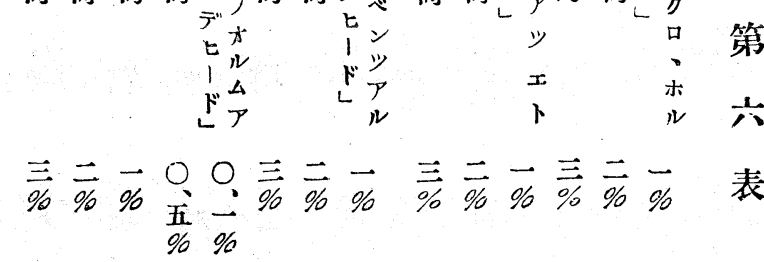

九九九九九九 九九 九

入八入入八九九九九九九

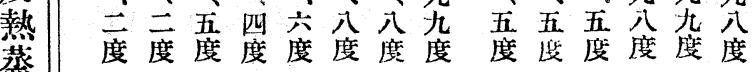

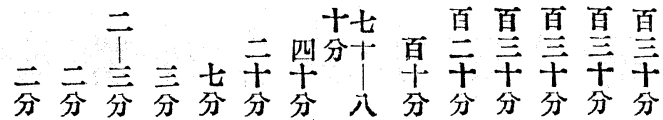

第<smiles>C[AlH]</smiles>

一 九 九

$\overrightarrow{0}$ 八九九九公九九

○五九卆无八九

度度度度度度度度度
表 五

\section{$=$ 二五}

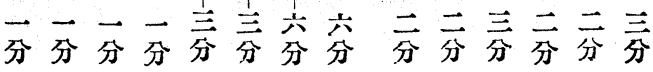

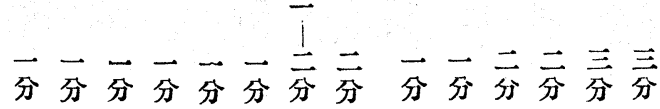

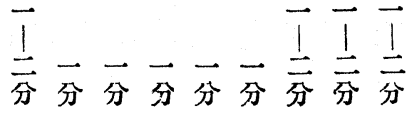

ク括 シ 最同同ンフ同同ルフ 試 ルセラ温所 盖

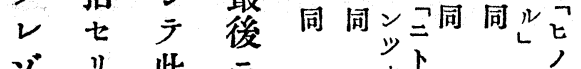

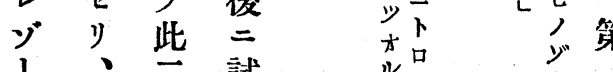

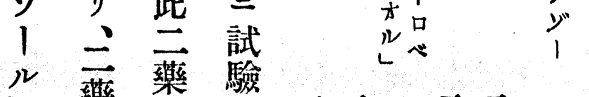

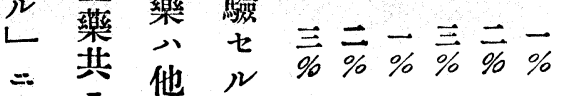

同 = 他

價甚編 公九九九九九九

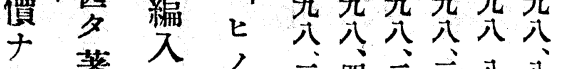

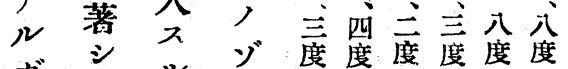

如 $キ$ 如

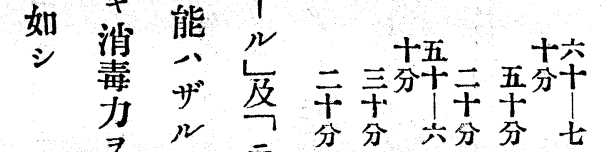

七

召学分分齐分

有

シ 吾 $\rightarrow$

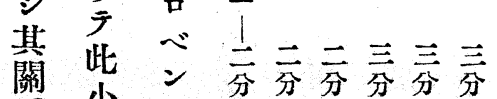

䇣 小㤗

兮表 オ 一

卢總 $\stackrel{2}{=} \frac{\overrightarrow{1}}{\text { 分分分分分分 }}$
第ノ 證 八㵊ル早入? 七ス現所稀 モ 以

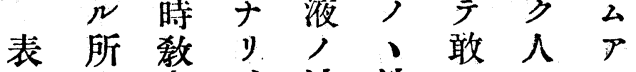
ナ室、消消厅人 y = 是毒毒警知 デ

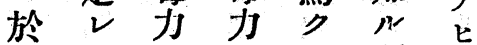
今 琶增, 二 所, 行 ク 加 斯 足 $=$ ト 且地 フ デ 、其 蒸 \%上斯 非然實 氟 近更 常地混 時 $=$ 二 瓜㗂 合 公利如迅水用有 二益 $\neq$ 速蒸 $モ$ 有

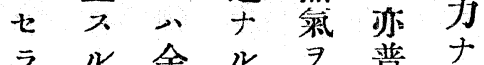
ラ

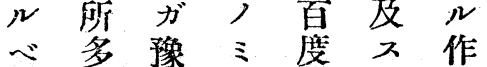
キカ期ナ

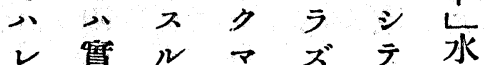


號九十五白三第誌雜會究研事醫堂天順六九八

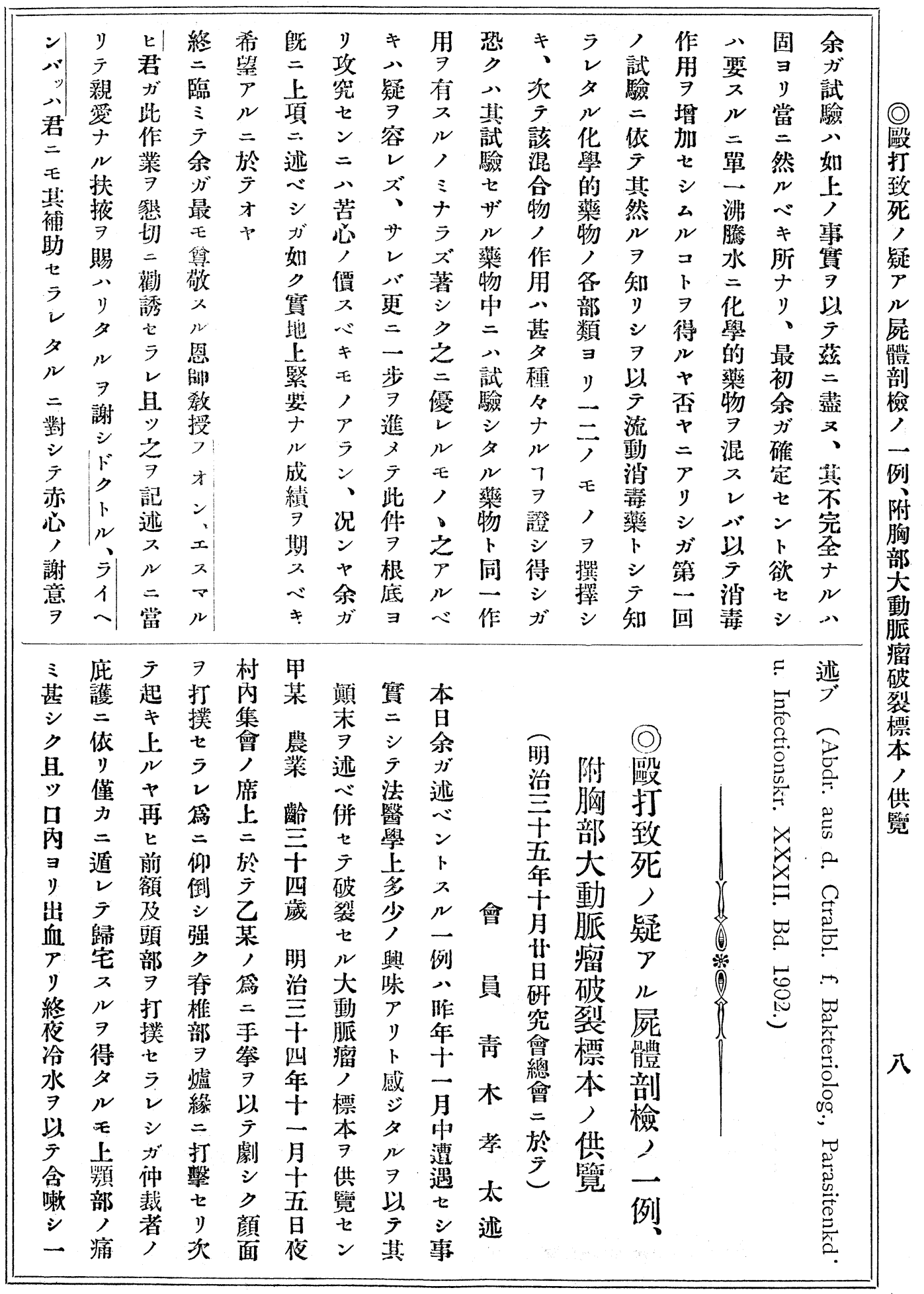

